\title{
DNA Methylation Alterations and Their Association with High Temperature Tolerance in Rice Anthesis
}

\author{
Bo Li ${ }^{1} \cdot$ Haiya Cai ${ }^{2} \cdot \mathrm{Ke} \mathrm{Liu}^{1} \cdot$ Bingzhuang An ${ }^{1} \cdot$ Rong Wang $^{1} \cdot$ Fang Yang $^{3} \cdot$ Changli Zeng $^{4} \cdot$ Chunhai Jiao $^{2}$. \\ Yanhao $\mathrm{Xu}^{2}$ (1)
}

Received: 27 October 2021 / Accepted: 19 January 2022 / Published online: 18 February 2022

(c) The Author(s) 2022

\begin{abstract}
DNA methylation is an important epigenetic mechanism involved in gene regulation under environmental stresses in plants. However, little information is available regarding its responses to high temperature (HT) and association with HT tolerance in rice. In this study, fourteen rice genotypes were classified into the susceptible, moderate, and tolerant groups by the high temperature susceptibility index (HTSI) after HT treatment. The changes of DNA methylation in rice anthesis under normal and HT30 conditions were investigated using methylation-sensitive amplified polymorphism31 (MSAP). The MSAP results showed that the DNA methylation level significantly increased in the susceptible rice group and decreased in the tolerant rice group under HT treatment, while no significant difference was observed in the moderate rice group. More hypomethylation events were detected in the tolerant rice group, while more hypermethylation was detected in the susceptible rice group. Forty-four differentially methylated epiloci (DME) were generated under both control and HT conditions, which can clearly distinguish the susceptible, moderate, and tolerant genotypes via PCoA analysis. Approximately $43.18 \%$ of DMEs were determined to be tolerance-associated epiloci (TAEs). 63.15\% TAEs were sequenced and annotated into 12 genes. Quantitative RT-PCR analysis showed that 12 TAE genes were mainly upregulated in 14 rice genotypes, and their expression levels were related to the HT tolerance of rice. Here, DEGs, generated from a number of genotypes, indicate higher probabilities for association with stress tolerance. Overall, these results suggest that DNA methylation regulation might play a key role in adaptation to HT stress in rice.
\end{abstract}

Keywords DNA methylation $\cdot$ High temperature tolerance $\cdot$ MSAP $\cdot$ Rice (Oryza sativa. L.)

Handling Editor: Mikihisa Umehara.

Changli Zeng

zengchangli6111@sohu.com

$\triangle$ Chunhai Jiao

jiaoch@hbaas.com

$\triangle$ Yanhao Xu

xyh@hbaas.com

1 Hubei Key Laboratory of Waterlogging Disaster and Agriculture Use of Wetland/Hubei Collaborative Innovation Centre for Grain Industry/Engineering Research Center of Ecology and Agriculture Use of Wetland, Ministry of Education, Yangtze University, Jingzhou 434025, Hubei, China

\section{Introduction}

DNA methylation mainly occurs in $\mathrm{CG}, \mathrm{CHG}$, and $\mathrm{CHH}$ $(\mathrm{H}=\mathrm{A}, \mathrm{C}$, or $\mathrm{T})$ at the 5 positions of cytosine, yielding 5-methylcytosine, which is a conserved epigenetic

2 Hubei Key Laboratory of Food Crop Germplasm and Genetic Improvement, Food Crops Institute, Hubei Academy of Agricultural Sciences, Wuhan 430064, Hubei, China

3 State Key Laboratory of Hybrid Rice, College of Life Sciences, Wuhan University, Wuhan 430072, Hubei, China

4 Hubei Engineering Research Center for Protection and Utilization of Special Biological Resources in the Hanjiang River Basin, Jianghan University, Wuhan 430056, Hubei, China 
mechanism for the regulation of gene expression (Zhang et al. 2018). Natural DNA methylation variation can regulate plant development and improve environmental adaptation (Alonso-Blanco et al. 2016; Alakärppä et al. 2018). DNA methylation has been reported to play important roles in plant adaptive responses to environmental stresses (Wang et al. 2016; Abid et al. 2017; Xia et al. 2017).

Stress-induced DNA methylation changes have been widely investigated under various abiotic stresses in many plants (Abid et al. 2017; Kaur et al. 2018; Duan et al. 2020). Studies based on a few contrasting tolerance genotypes have reported the complex relationship between DNA methylation and stress tolerance. A previous study reported that the DNA methylation level in a drought-tolerant wheat genotype was lower than that in a drought-susceptible wheat genotype under drought conditions (Kaur et al. 2018). A higher DNA methylation level was also detected in the drought-tolerant wheat genotype than in the drought-susceptible wheat genotype (Duan et al. 2020). In rice, the differentially methylated regions (DMRs) among different cultivars were reported to be associated with the variability of drought tolerance (Garg et al. 2015). However, another study reported that large proportions of DMRs detected between two cultivars were also reported as not stress-relevant (Wang et al. 2016). These studies highlight the need for more studies to uncover the relationship between DNA methylation and environmental stress tolerance.

High temperature (HT) is regarded as one of the most detrimental stresses among constantly changing environmental factors (Fahad et al. 2016, 2019; Chang-Fung-Martel et al. 2017; Harrison et al. 2017; Kan and Lin 2021). Rice (Oryza sativa L.) is an internationally vital cereal as well as a heat-sensitive plant (Liu et al. 2019; Wu et al. 2020). The anthesis stage of rice is the most sensitive to HT stress, which can induce spikelet sterility and directly reduce rice yield (Mu et al. 2017; Yan et al. 2017; Fahad et al. 2018). To date, increasing evidence has indicated that epigenetic modification plays important roles in plants in the response to elevated temperature (Gao et al. 2014; Liu et al. 2018; Qian et al. 2019; Zhao et al. 2020). DNA methylation is involved in the regulation of genes implicated in the plant response to HT stress (Qian et al. 2019). In Brassica napus, HT stress induced the methylation variation to increase more in a heat-sensitive genotype than in a heat-tolerant genotype (Gao et al. 2014). However, few studies have investigated the relationship between DNA methylation responses and HT stress tolerance during the rice anthesis stage.

The methylation-sensitive amplification polymorphism (MSAP) approach is a powerful and economic method to explore genome-wide DNA methylation. MSAP is based on the differential sensitivity to site-specific cytosine methylation of two restriction enzymes ( $H p a \mathrm{II}$ and $M s p \mathrm{I}$ ), which has been widely used for the detection of DNA cytosine methylation levels in plants (Wang et al. 2015; Xia et al. 2017; Duan et al. 2020; Pan et al. 2020).

In this study, we applied MSAP to investigate the DNA methylation responses in rice spikelets at the anthesis stage under control (CK) and high temperature (HT) conditions. Furthermore, a number of HT-tolerant and HT-susceptible rice accessions were involved in this study to explore the relationships between DNA methylation and HT tolerance ability in rice. The present findings provide useful epigenetic information for further understanding the molecular mechanism of HT stress tolerance in rice.

\section{Materials and Methods}

\section{Plant Materials and Cultivation}

Fourteen rice accessions were used in this study (Table 1). Seeds were surface-sterilized and germinated at room temperature in the dark. The germinated seeds were then transferred to a seedling nursery at Yangtze University, Jingzhou City, Hubei, China. Seedlings were transplanted at 20 days old into plastic pots $(30 \mathrm{~cm}$ height and $30 \mathrm{~cm}$ diameter) filled with $12.5 \mathrm{~kg}$ of soil and $8 \mathrm{~g}$ of compound fertilizer (with a ratio of N, P, and K of 26:10:15) (Yan et al. 2017). For each pot, twenty seedlings were planted.

\section{High Temperature Treatment and Sampling}

The control and high temperature treatments were performed with six pots as one biological replicate. All treatments were performed in three biological replicates. A split plot in a completely randomized design was used in this study. For each genotype, the plants were grown to the heading stage and then transferred before anthesis to a growth chamber (AGC-MR, Zhejiang Qiushi Environment Co., Ltd, China). The HT treatment was started after flowering (50\% of the main stem flowering) and tagged individuals that flowered on the same day. The average daily temperature was set to $26{ }^{\circ} \mathrm{C}$ and $33{ }^{\circ} \mathrm{C}$ in the $\mathrm{CK}$ and HT treatments, respectively (Table S1). The air temperature was dynamically controlled in accordance with the diurnal variation in air temperature simulating local typical heat weather conditions with relative humidities of $70 \%$ and $80 \%$ for day and night. After $48 \mathrm{~h}$ of treatment, the tagged spikelets of each genotype were collected (randomly mixed more than five spikelets), frozen in liquid nitrogen, and stored at $-80{ }^{\circ} \mathrm{C}$ for further use. Furthermore, the rest of the plants moved to the control condition and were cultivated until maturity. The seed-set percentage was investigated by counting twenty panicles of each genotype. 
Table 1 The changes in seed-set percentage in 14 rice genotypes under HT condition

\begin{tabular}{llllll}
\hline \multirow{2}{*}{$\begin{array}{l}\text { Sample } \\
\text { Number }\end{array}$} & Varieties & \multicolumn{2}{l}{ Seed-set percentage $(\%)$} & HTSI & HT tolerance degree \\
\cline { 3 - 4 } & & CK & HT & \\
\hline S1 & Dianrui 409B & $88.03 \pm 3.07^{*}$ & $37.07 \pm 2.75$ & $0.58 \pm 0.03^{\mathrm{a}}$ & Susceptible \\
S2 & Wenxiangnuo & $83.97 \pm 4.51^{*}$ & $41.10 \pm 2.65$ & $0.51 \pm 0.03^{\mathrm{a}}$ & Susceptible \\
S3 & IR64 & $89.47 \pm 6.16^{*}$ & $43.97 \pm 3.80$ & $0.51 \pm 0.04^{\mathrm{a}}$ & Susceptible \\
S4 & Mianhui 101 & $81.33 \pm 2.05^{*}$ & $40.53 \pm 6.51$ & $0.50 \pm 0.08^{\mathrm{a}}$ & Susceptible \\
M1 & Zhongnong 4 & $87.67 \pm 3.71^{*}$ & $62.53 \pm 4.92$ & $0.29 \pm 0.06^{\mathrm{b}}$ & Moderate \\
M2 & Gu 154B & $89.33 \pm 3.89^{*}$ & $64.87 \pm 4.10$ & $0.27 \pm 0.05^{\mathrm{b}}$ & Moderate \\
M3 & Zhengdao5 & $92.00 \pm 2.42^{*}$ & $70.37 \pm 3.01$ & $0.24 \pm 0.03^{\mathrm{b}}$ & Moderate \\
M4 & Xiaomazhan & $91.30 \pm 2.91^{*}$ & $63.10 \pm 7.70$ & $0.31 \pm 0.08^{\mathrm{b}}$ & Moderate \\
M5 & Ximaxian & $91.47 \pm 3.66^{*}$ & $65.53 \pm 3.56$ & $0.28 \pm 0.04^{\mathrm{b}}$ & Moderate \\
M6 & Chengnongshuijing & $88.30 \pm 2.43^{*}$ & $60.93 \pm 5.58$ & $0.31 \pm 0.06^{\mathrm{b}}$ & Moderate \\
T1 & Zhankenuo & $90.90 \pm 3.27$ & $84.07 \pm 2.83$ & $0.08 \pm 0.03^{\mathrm{c}}$ & Tolerant \\
T2 & Huangsiguizhan & $91.23 \pm 2.10^{*}$ & $84.07 \pm 3.67$ & $0.08 \pm 0.04^{\mathrm{c}}$ & Tolerant \\
T3 & N22 & $90.63 \pm 2.99$ & $87.18 \pm 3.14$ & $0.04 \pm 0.03^{\mathrm{c}}$ & Tolerant \\
T4 & Esiniu & $90.90 \pm 2.36$ & $86.33 \pm 4.40$ & $0.05 \pm 0.05^{\mathrm{c}}$ & Tolerant \\
\hline
\end{tabular}

The asterisk * indicates significant difference in seed-set percentage between CK and HT at the level of 0.05 , according to ANOVA

Different letters indicate significant difference in HSTI among the 14 rice genotypes at the level of 0.05 , according to ANOVA

\section{Rice High Temperature Tolerance Assessment}

The high temperature susceptibility index (HTSI) was used to assess the variability in high temperature stress among rice genotypes with the following equation: $\mathrm{HTSI}=(\mathrm{CS} \%-\mathrm{HS} \%) / \mathrm{CS} \%$, where $\mathrm{CS} \%$ and $\mathrm{HS} \%$ were the average seed-set percentage of each accession under the CK and HT treatments, respectively. IR64 and N22 were used as high temperature susceptible and tolerant references, respectively (Mu et al. 2017). The significant differences in seedset percentage and HTSI were analyzed by SPSS 19.0 using the one-way analysis of variance (ANOVA) method (SNK method) at the 0.05 level. Additionally, the fourteen rice genotypes were further classified into three groups (tolerant, moderate, and susceptible groups) based on the significant differences in HTSI.

\section{DNA Methylation Analysis by MSAP Approach}

Total DNA was isolated using the CTAB procedure, and the procedure of MSAP analysis was described in the previous research ( $\mathrm{Li}$ et al. 2020). The MSAP technique was performed using a pair of isoschizomers, HpaII/MspI (Thermo Fisher Scientific, USA), which possess differential sensitivity to cytosine methylation at the 5'-CCGG-3' site and combined with EcoRI. The adaptors, preselective primers, and 20 paired selective primers are listed in Table S2. The PCR products were separated by a Fragment Analyzer Automated CE System (AATI, USA) using the DNF-900 dsDNA Reagent Kit 35-500 bp (AATI, USA). The MSAP data were exported by PROSize version 2.0 software (AATI, USA) and transformed into a binary character matrix using "1" or " 0 " to indicate the presence or absence of bands. Only the consistent epiloci among the three biologicals were used for future analysis.

\section{DNA Methylation Changes and Correlations with HTSI}

The MSAP bands were divided into four epigenotypes. Type I represented non-methylation, in which MSAP bands appeared in both EcoRI/HpaII and EcoRI/MspI combinations (11). Type II represented hemimethylation, in which bands appeared only in EcoRI/HpaII but not in EcoRI/MspI (10). Type III generated bands only in EcoRI/MspI but not in EcoRI/HpaII and indicated inner methylation of doublestranded DNA (full methylation) (01). Type IV represented the absence of a band in both EcoRI/HpaII and EcoRI/MspI combinations (00), which were determined to be full methylation.

The similarity in DNA methylation between two rice genotypes or groups was calculated according to Xia et al. (2017), which was defined as the proportion of an epilocus possessing the same epigenotype to the total epiloci. The total methylation level of each group was calculated as follows: Total methylated bands $(\%)=[(\mathrm{II}+\mathrm{III}+\mathrm{IV}) /$ $(\mathrm{I}+\mathrm{II}+\mathrm{III}+\mathrm{IV})] \times 100$. The hemimethylation level was calculated as follows: hemimethylated bands $(\%)=[(\mathrm{II}) /$ $(\mathrm{I}+\mathrm{II}+\mathrm{III}+\mathrm{IV})] \times 100$. The full methylation level of each 
sample was calculated as follows: full methylated bands $(\%)=[(\mathrm{III}+\mathrm{IV}) /(\mathrm{I}+\mathrm{II}+\mathrm{III}+\mathrm{IV})] \times 100$.

A total of sixteen DNA methylation pattern alterations from CK to HT permutations were classified into hypomethylation, hypermethylation, and unchanged (Table 3). The significant differences of DNA methylation levels and the proportion of hypomethylation, hypermethylation, and unchanged between or within each group were analyzed via independent t-test or one-way ANOVA (SNK method) using SPSS 19.0.

To test the associations of DNA methylation with HT tolerance, correlation analysis was conducted between the averaged HTSI and the averaged change ratio of DNA methylation levels of each rice group, as well as the averaged proportion of hypomethylation and hypermethylation via Pearson's coefficient (Xia et al. 2017).

\section{The Identification of Tolerance-Associated Epiloci Under HT Stress}

Hierarchical analysis of molecular variance (AMOVA) was conducted to investigate the epigenetic variations ( among the tolerant, moderate, and susceptible groups using GenAlex 6.5 (Peakall and Smouse 2006). Thus, ФCT could represent the level of epigenetic differences between different tolerant materials. The top 5\% epigenetic difference (top $5 \%$ highest $\Phi C \mathrm{C}$ ) epiloci between groups were determined to be differentially methylated epiloci (DME) (Xia et al. 2017). Principal coordinates analysis (PCoA) was conducted to test whether the DMEs could be separated based on the tri distance matrix calculated from the data of DMEs or total epiloci via GenAlex 6.5.

Furthermore, if a DME was associated with HTSI, the different epigenotypes on this DME should impact the HTSI. The average HTSI from the same epigenotype rice accession was used to represent the HTSI of each different epigenotype on this DME. The independent $t$ test or one-way ANOVA (SNK method) was used to explore the tolerance-associated epilocus (TAE) from all the DMEs if a significant difference in average HTSI was detected among different epigenotypes at a DME.

\section{Sequencing and Characterization of TAEs and Their Expression Analysis}

The PCR products from 7 pairs of selective primers were re-separated in a $6 \%$ denaturing polyacrylamide gel (Table S2). Eighteen polymorphic fragments, including 12 TAEs and 6 non-TAEs, were selected and recycled from the gel and crushed in $20 \mu \mathrm{L}$ of TE buffer. The recovered fragments were reamplified with the same primer set. The purified PCR products were cloned with T-vector (Takara, China) for sequencing. Homologous analysis and gene annotation of PCR sequences were conducted using the MSU Rice Genome Annotation Project Database (http:// rice.plantbiology.msu.edu/index.shtml).

To detect the relative expression levels of selected genes among the susceptible, moderate, and tolerant groups, the total RNA of each rice genotype was isolated from the spikelets using TRIzol (Invitrogen, USA) and dissolved in DEPC-treated $\mathrm{ddH}_{2} \mathrm{O}$. cDNA synthesis for quantitative RT-PCR (qRT-PCR) analysis was performed using UEIris RT mix with a DNase kit (All-in-One, US Everbright, China). qRT-PCR was run on a QuantStudio ${ }^{\mathrm{TM}}$ 6 Flex real-time PCR system (Applied Biosystems, USA) using $2 \times$ SYBR Green qPCR Master mix (S2014, US Everbright, China). The gene-specific primers for qRTPCR are listed in Table S2. All qRT-PCR analyses were performed with three biological replicates and 3 technical duplications. The housekeeping gene Actin was used as an internal control to calculate the relative gene expression levels in each group ( $2^{-\Delta \Delta \mathrm{Ct}}$ method). Heatmaps of the gene expression were illustrated using TBtools (Chen et al. 2020a).

\section{Statistical Analysis}

Data were statistically analyzed by one-way ANOVA (independent t-test or SNK methods) with a significance level of $P<0.05$ using SPSS 18.0 statistical software.

\section{Results}

\section{High Temperature Tolerance Variations Among 14 Rice Genotypes}

The average seed-set percentages of all rice genotypes ranged from $81.33 \%$ to $92.00 \%$ under CK conditions (Table 1). After HT treatment, except for Zhankenuo, N22, and Esiniu, the seed-set percentages decreased by 23.51-57.89\% when compared with the corresponding control $(P<0.05)$ (Table 1). The HTSI of the 14 rice genotypes ranged from 0.04 to 0.58 (Table 1). Significant differences in HTSI were detected among the 14 rice genotypes, which divided the rice accessions into tolerant, moderate, and susceptible groups (Table 1). The accessions of Zhankenuo, Huangsiguizhan, N22, and Esiniu were classified into the tolerant group (T1-T4), as there was no significant difference in HTSI among these 4 genotypes. The accessions of Mianhui 101, IR64, Dianrui 409B, and Wenxiangnuo were classified into the susceptible group (S1-S4), and the remaining accessions were classified into the moderate group (M1-M6) (Table 1). 


\section{Epigenetic Background Differences Among the Fourteen Rice Genotypes}

A total of 443 informative epiloci were detected by twenty pair primers under CK and HT conditions (Fig. 1). The average similarity of DNA methylation between each two genotypes was $37.72 \%$. In the CK condition, the average similarity of DNA methylation within susceptible, moderate, and tolerant groups was $37.96 \%, 38.52 \%$, and $33.56 \%$, respectively. No significant difference was detected within each group or among the three groups in CK (Fig. 2). Similarly, no significant differences were detected within each group and among the three groups in HT treatment, with $40.58 \%, 37.37 \%$, and $43.7 \%$ in the susceptible group, moderate group, and tolerant group, respectively (Fig. 2). These results showed that the fourteen rice genotypes had no epigenetic background differences.

\section{DNA Methylation Level Changes Under HT Treatments}

In the susceptible group, HT treatment increased the methylation level. The average full $(36.23 \%)$ and total methylation $(46.50 \%)$ increased significantly $(P<0.05)$, ranging from $36.12 \%$ to $40.41 \%$ and $41.99-51.69 \%$ after HT treatment, while no significant difference was observed in average hemimethylation (10.27\%), ranging from $7.22 \%$ to $12.87 \%$ (Table 2). In the moderate group, HT treatment induced changes in the hemi-, full, and total methylation levels that varied among the genotypes (Table 2). However, no significant difference in the average methylation level was detected between the CK and HT treatments. In the tolerant group, HT stress-induced full and total methylation levels decreased significantly. The full methylation levels ranged from $24.83 \%$ to $26.19 \%$ with an average of $25.85 \%$, and the total methylation levels ranged from $31.83 \%$ to $37.02 \%$ with an average of $35.16 \%$ (Table 2).

\section{DNA Methylation Patterns Alterations Under HT Stress}

A total of 16 DNA methylation alternative patterns were scored in three groups from CK to HT, which could be categorized into hypomethylation, hypermethylation, and methylation unchanged (Table 3). In the susceptible group, the proportion of hypermethylation (29.91\%) was significantly higher than the proportion of hypomethylation (22.86\%), ranging from $25.06 \%$ to $32.51 \%$ and $21.90 \%$ to $24.38 \%$, respectively. The moderate group had similar alteration patterns of hypomethylation $(25.43 \%)$ and hypermethylation $(27.50 \%)$ under HT stress, which ranged from $18.74 \%$ to $32.51 \%$ and 23.25 to $33.86 \%$, respectively (Table 3 ). In contrast, a significantly higher proportion of hypomethylation events $(27.31 \%)$ was observed in the tolerant group than

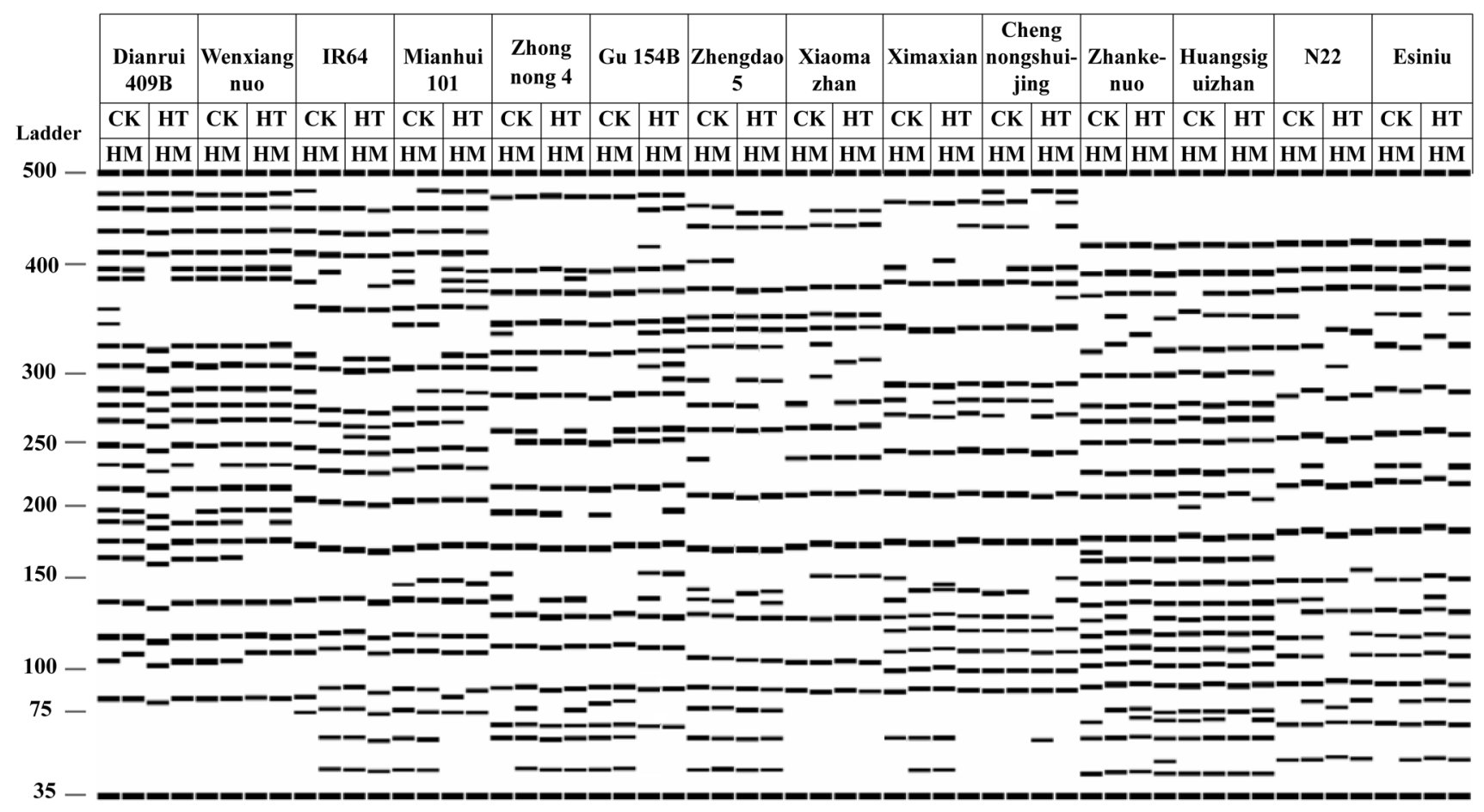

Fig. 1 A representative MSAP result of 14 rice genotypes under CK and HT conditions using the primer combination EcoRI+TGC with $H p a \mathrm{II} / M s p \mathrm{I}+\mathrm{CAG}$. H represents digestion with EcoRI/HpaII, M represents digestion with EcoRI/MspI 
Fig. 2 Averaged similarity of DNA methylation between two rice genotypes within each group or between each two groups in the CK and HT conditions. Bars indicate standard deviation (Color figure online)
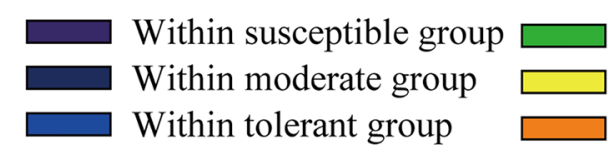

Between susceptible and moderate groups Between susceptible and tolerant groups Between moderate and tolerant groups

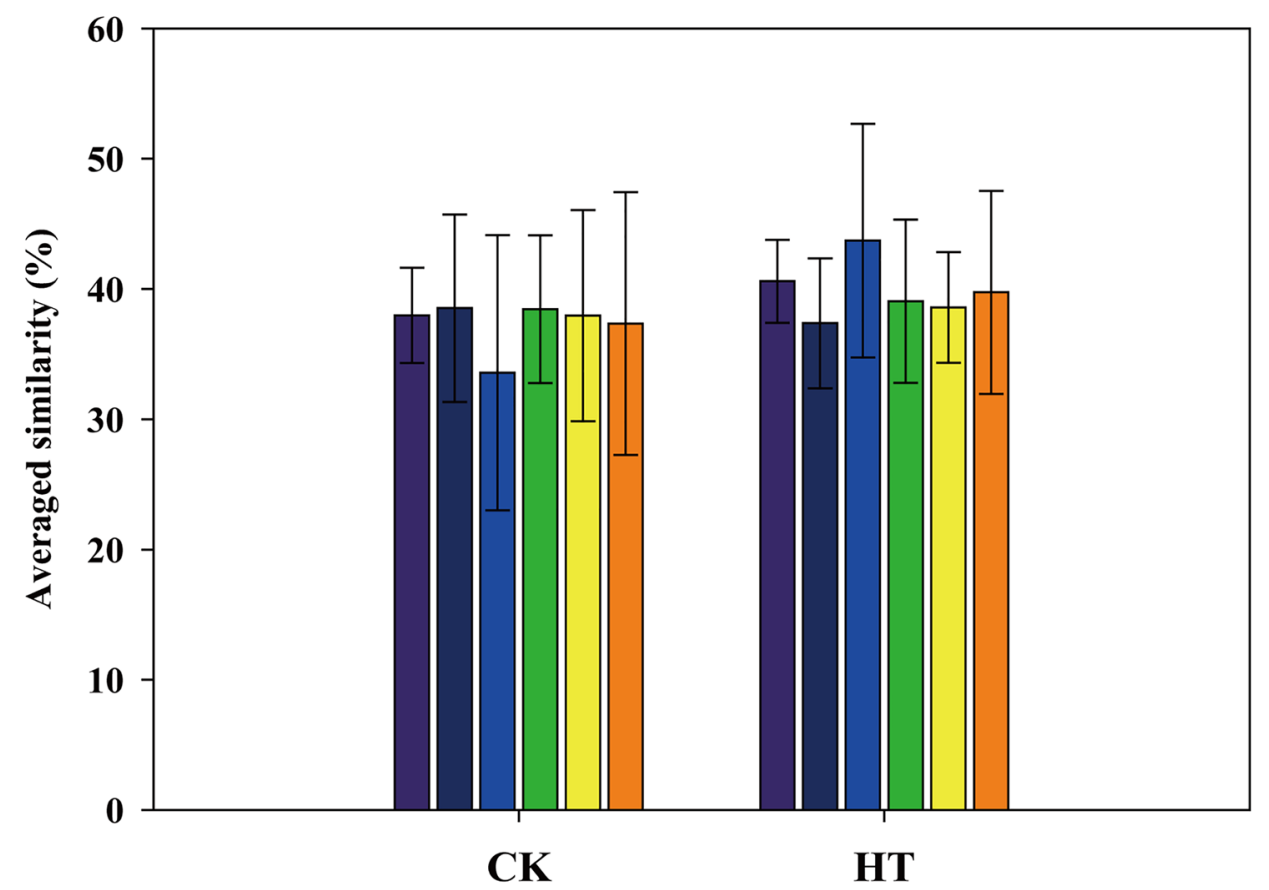

hypermethylation $(20.20 \%)$ under HT stress, which ranged from $24.15 \%$ to $28.67 \%$ and $13.77 \%$ to $24.60 \%$, respectively (Table 3).

\section{Correlations Between DNA Methylation Response Changes and Rice HTSI}

In general, HT stress-induced DNA methylation levels increased in the susceptible group, remained unchanged in the moderate group, and decreased in the tolerant group. To further investigate the correlation of DNA methylation levels and pattern alterations with HT tolerance, Pearson correlation analysis was conducted between the averaged change ratios of DNA methylation levels or pattern alterations with HTSI in the three rice groups (Table 4). The results showed that the parameter "the proportion of hypomethylation" correlated negatively with HTSI $(P<0.05)$, indicating a positive correlation between hypomethylation level and HT tolerance in rice. A positive correlation was observed between HTSI and "the change ratio of full methylation level from CK to HT," indicating that the increase in full methylation under HT treatment was negatively correlated with HT tolerance (Table 4). No significant correlations were observed between HTSI and the change ratio of hemimethylation or total methylation from CK to HT. These results were consistent with the DNA methylation pattern changes in which the tolerant genotypes had a high proportion of hypomethylation.

\section{Impact of Differentially Methylated Epiloci on Rice HTSI}

A total of 44 differentially methylated epiloci (DMEs) were determined among susceptible, moderate, and tolerant groups under CK (22 DMEs) and HT (22 DMEs) conditions via AMOVA analysis (Table S3). The rice accessions were separated into susceptible, moderate, and tolerant groups by PCoA in both the CK and HT treatments by the 44 DMEs (Fig. 3a and b). However, no apparent tolerance-associated groups were clustered among the rice accessions when total epiloci were used by PCoA under both the CK and HT conditions (Fig. 3c and d).

Additionally, 9 of 22 DMEs in CK (40.91\%) and 10 of 22 DMEs in HT (45.46\%) were detected as tolerance-associated epiloci (TAEs). On these DMEs, there were significant differences in HTSI between rice accessions with different epigenotypes (Table 5).

\section{Sequencing and Expression Analysis of Polymorphic Fragments}

Eighteen polymorphic MSAP fragments from 7 MSAP primer combinations were sequenced, 12 of which were detected as TAEs ( 2 from the CK condition and 10 from the HT condition), and 6 of them were non-TAEs (Table S4). The size of the sequenced bands ranged from 70 to $444 \mathrm{bp}$ 


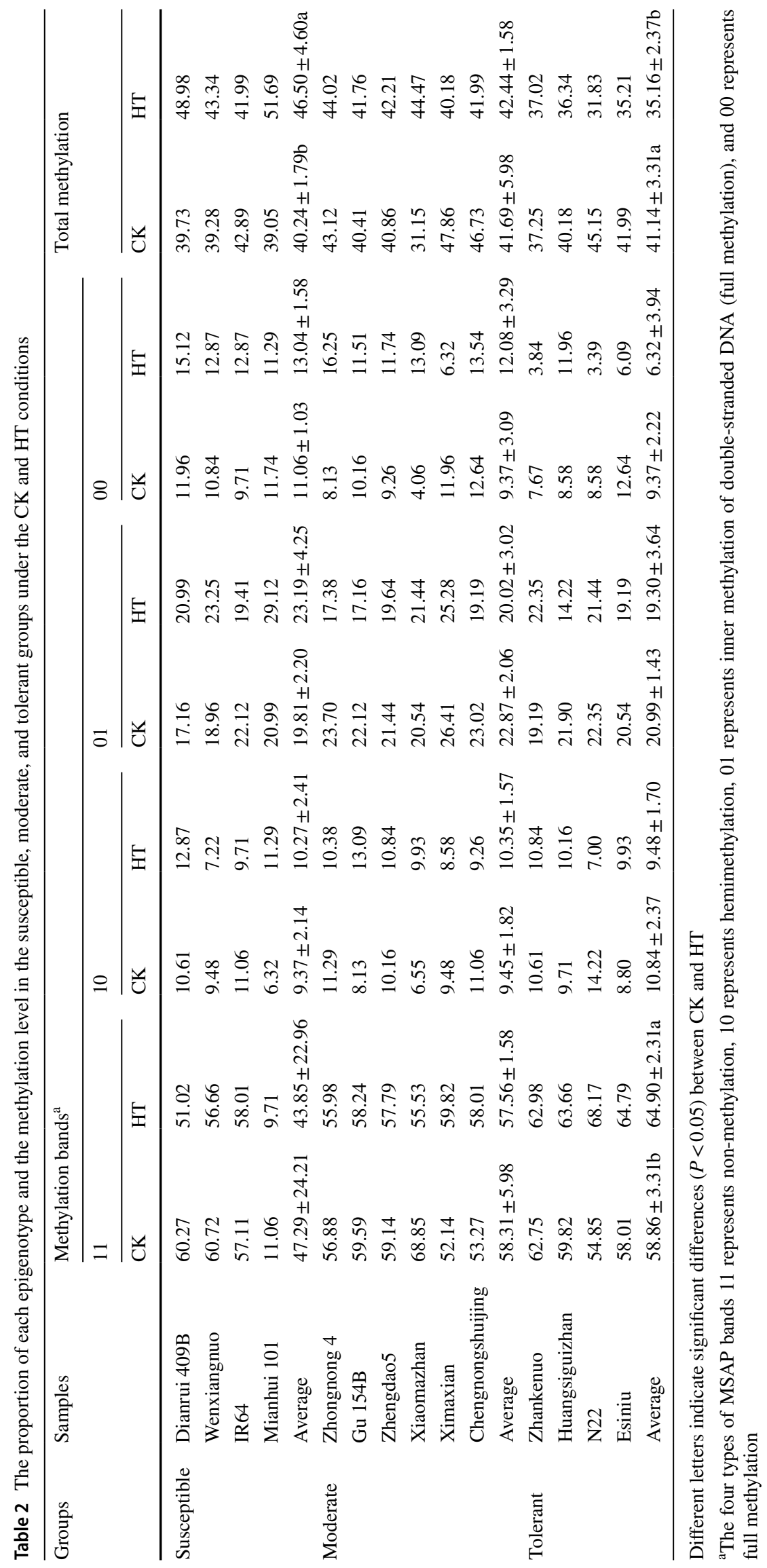




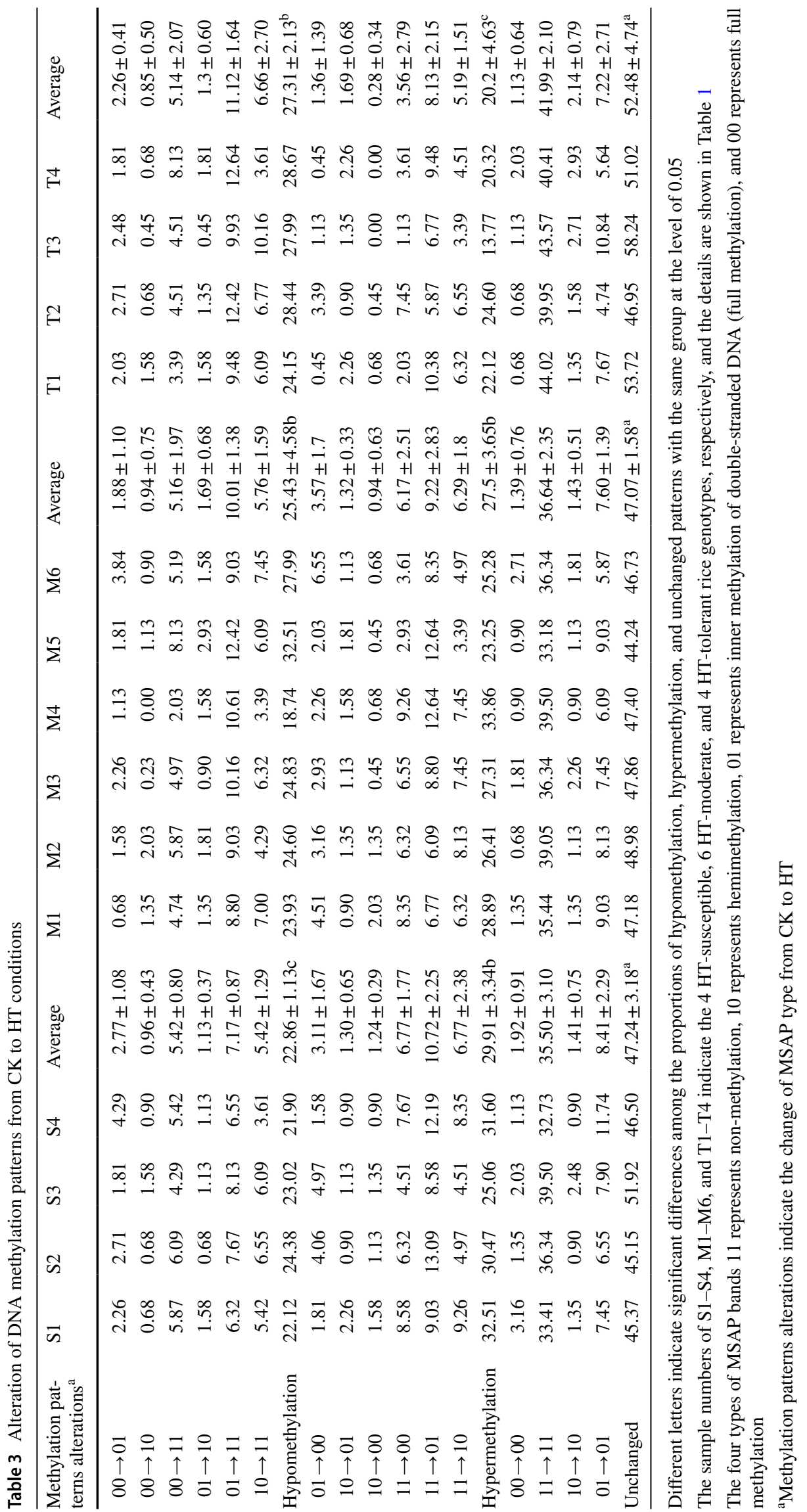


Table 4 Correlation analysis between DNA Methylation parameters and the high temperature susceptibility index

\begin{tabular}{lcc}
\hline DNA methylation parameters & $H T S I$ & \\
\cline { 3 - 3 } & Coefficient & $P$ value \\
\hline The change ratio of full methylation level from CK to HT & $1.000^{*}$ & 0.019 \\
The change ratio of hemimethylation level from CK to HT & 0.853 & 0.350 \\
The change ratio of total methylation level from CK to HT & 0.996 & 0.055 \\
The proportion of hypermethylation & 0.953 & 0.197 \\
The proportion of hypomethylation & $-0.998^{*}$ & 0.041 \\
\hline
\end{tabular}

The asterisks * indicate a significant correlation at the level of 0.05 a

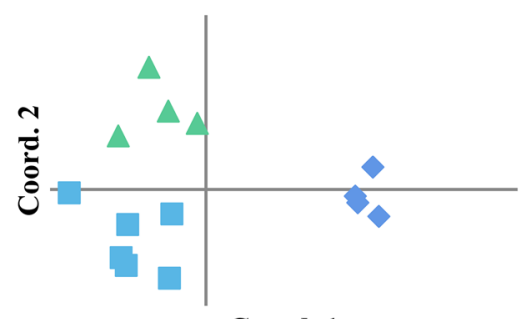

Coord. 1

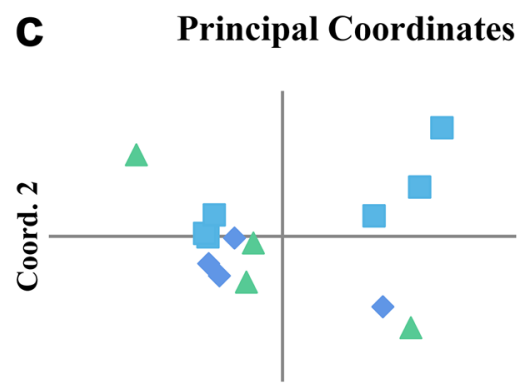

Coord. 1
Susceptible group

Moderate group

$\triangle$ Tolerant group

Susceptbile grou

Moderate group

Tolerant group

Fig. 3 Separations of susceptible, moderate, and tolerant genotypes by principal coordinate analysis under CK (a and c) and HT stress (b and d) conditions using differentially methylated epiloci ( $\mathbf{a}$ and $\mathbf{b}$ ) and total epiloci (c and d) (Color figure online)

(Table S4). BLASTN results indicated that the 18 epiloci were annotated into 18 genes, which are involved in several biological processes, such as stress response, epigenetic regulation, metabolic process, and signal transduction (Table S4).

The qRT-PCR results showed that most of the 12 TAE genes were upregulated after HT treatment in the 14 rice genotypes (relative expression value $>1$ ) (Fig. 4a). Fourteen rice genotypes were clustered into three groups according to the gene expression levels. The clustering result was similar to the HT tolerance classification of the 14 rice genotypes (Table 1), although the accessions of M5 (Ximaxian) and M6 (Chengnongshuijing) were clustered into the HT-susceptible group (Fig. 4a). Moreover, 6 non-TAE genes were mainly downregulated or expressed at low levels under HT conditions (relative expression value $<1$ ), and there was no

\section{b Principal Coordinates (PCoA)}

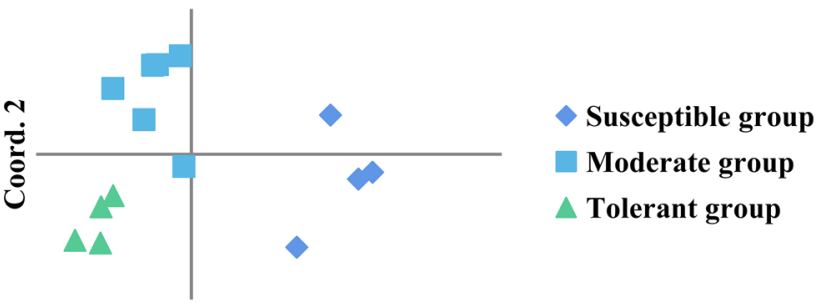

Coord. 1

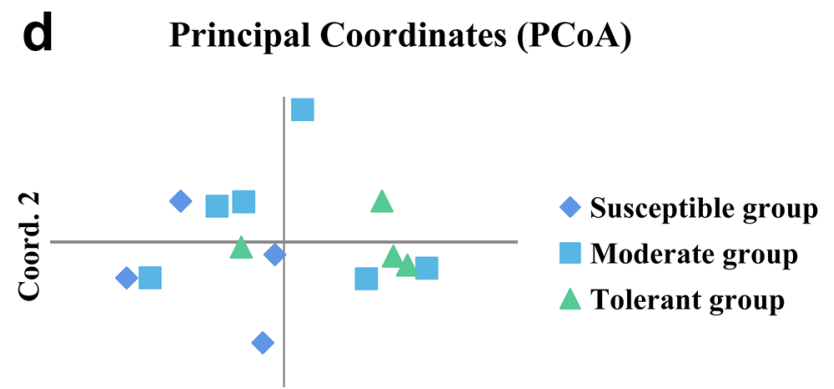

Coord. 1 obvious HT tolerance classification in the 14 rice genotypes (Fig. 4b).

\section{Discussion}

\section{High Temperature-Induced Dramatic DNA Methylation Alterations}

Epigenetics, such as histone modification and DNA methylation patterns, are altered to enhance DNA accessibility by chromatin relaxation under heat stress (Lamelas et al. 2020). In this study, 14 rice genotypes were used, which were classified into HT-susceptible, HT-moderate, and HT-tolerant groups. The methylation level of rice spikelets was significantly decreased in the tolerant group (from an average of 
Table 5 Epigenotypes on tolerance-associated epiloci have significantly different HTSI in CK and HT conditions

\begin{tabular}{|c|c|c|c|c|}
\hline Condition & TAEs & $\begin{array}{l}\text { Main epig- } \\
\text { enotypes }\end{array}$ & Frequency & HTSI \\
\hline \multirow[t]{24}{*}{ CK } & \multirow[t]{3}{*}{ Epiloci31 } & 11 & $4 / 14$ & $0.12 \pm 0 .^{11 \mathrm{~b}}$ \\
\hline & & 00 & $6 / 14$ & $0.28 \pm 0.15^{\mathrm{ab}}$ \\
\hline & & 01 & $3 / 14$ & $0.47 \pm 0.14^{\mathrm{a}}$ \\
\hline & \multirow[t]{3}{*}{ Epiloci102 } & 11 & $8 / 14$ & $0.31 \pm 0.14^{\mathrm{b}}$ \\
\hline & & 00 & $2 / 14$ & $0.55 \pm 0.05^{\mathrm{a}}$ \\
\hline & & 01 & $4 / 14$ & $0.11 \pm 0.11^{\mathrm{c}}$ \\
\hline & \multirow[t]{2}{*}{ Epiloci267 } & 11 & $9 / 14$ & $0.22 \pm 0.18^{b}$ \\
\hline & & 10 & $4 / 14$ & $0.46 \pm 0.10^{\mathrm{a}}$ \\
\hline & \multirow[t]{2}{*}{ Epiloci317 } & 11 & $6 / 14$ & $0.40 \pm 0.21^{\mathrm{a}}$ \\
\hline & & 01 & $8 / 14$ & $0.21 \pm 0.12^{\mathrm{b}}$ \\
\hline & \multirow[t]{2}{*}{ Epiloci328 } & 11 & $11 / 14$ & $0.35 \pm 0.15^{\mathrm{a}}$ \\
\hline & & 10 & $3 / 14$ & $0.06 \pm 0.02^{\mathrm{b}}$ \\
\hline & \multirow[t]{2}{*}{ Epiloci329 } & 11 & $10 / 14$ & $0.35 \pm 0.17^{\mathrm{a}}$ \\
\hline & & 10 & $4 / 14$ & $0.13 \pm 0.12^{\mathrm{b}}$ \\
\hline & \multirow[t]{3}{*}{ Epiloci346 } & 11 & $5 / 14$ & $0.20 \pm 0.13^{\mathrm{b}}$ \\
\hline & & 00 & $5 / 14$ & $0.19 \pm 0.12^{b}$ \\
\hline & & 01 & $3 / 14$ & $0.51 \pm 0.01^{\mathrm{a}}$ \\
\hline & \multirow[t]{4}{*}{ Epiloci360 } & 11 & $7 / 14$ & $0.26 \pm 0.16^{\mathrm{ab}}$ \\
\hline & & 00 & $3 / 14$ & $0.13 \pm 0.12^{\mathrm{b}}$ \\
\hline & & 10 & $2 / 14$ & $0.38 \pm 0.19^{\mathrm{ab}}$ \\
\hline & & 01 & $2 / 14$ & $0.54 \pm 0.06^{\mathrm{a}}$ \\
\hline & \multirow[t]{3}{*}{ Epiloci384 } & 11 & $7 / 14$ & $0.19 \pm 0.13^{b}$ \\
\hline & & 10 & $3 / 14$ & $0.53 \pm 0.04^{\mathrm{a}}$ \\
\hline & & 01 & $3 / 14$ & $0.34 \pm 0.15^{\mathrm{ab}}$ \\
\hline \multirow[t]{24}{*}{ HT } & \multirow[t]{3}{*}{ Epiloci16 } & 11 & $6 / 14$ & $0.26 \pm 0.19^{\mathrm{ab}}$ \\
\hline & & 00 & $6 / 14$ & $0.40 \pm 0.12^{\mathrm{a}}$ \\
\hline & & 01 & $2 / 14$ & $0.06 \pm 0.03^{b}$ \\
\hline & \multirow[t]{2}{*}{ Epiloci44 } & 11 & $10 / 14$ & $0.36 \pm 0.16^{\mathrm{a}}$ \\
\hline & & 01 & $3 / 14$ & $0.06 \pm 0.02^{\mathrm{b}}$ \\
\hline & \multirow[t]{2}{*}{ Epiloci185 } & 00 & $2 / 14$ & $0.55 \pm 0.05^{\mathrm{a}}$ \\
\hline & & 01 & $12 / 14$ & $0.25 \pm 0.16^{\mathrm{b}}$ \\
\hline & \multirow[t]{2}{*}{ Epiloci198 } & 00 & $4 / 14$ & $0.47 \pm 0.13^{\mathrm{a}}$ \\
\hline & & 01 & $9 / 14$ & $0.21 \pm 0.15^{\mathrm{b}}$ \\
\hline & \multirow[t]{2}{*}{ Epiloci226 } & 11 & $12 / 14$ & $0.33 \pm 0.16^{\mathrm{a}}$ \\
\hline & & 10 & $2 / 14$ & $0.05 \pm 0.01^{\mathrm{b}}$ \\
\hline & \multirow[t]{3}{*}{ Epiloci233 } & 11 & $6 / 14$ & $0.14 \pm 0.12^{b}$ \\
\hline & & 00 & $2 / 14$ & $0.28 \pm 0.01^{\mathrm{ab}}$ \\
\hline & & 01 & $6 / 14$ & $0.48 \pm 0.10^{\mathrm{a}}$ \\
\hline & \multirow[t]{3}{*}{ Epiloci238 } & 11 & $7 / 14$ & $0.16 \pm 0.13^{b}$ \\
\hline & & 00 & $2 / 14$ & $0.26 \pm 0.02^{b}$ \\
\hline & & 01 & $5 / 14$ & $0.48 \pm 0.11^{\mathrm{a}}$ \\
\hline & \multirow[t]{2}{*}{ Epiloci244 } & 11 & $8 / 14$ & $0.34 \pm 0.11^{\mathrm{a}}$ \\
\hline & & 10 & $5 / 14$ & $0.15 \pm 0.20^{\mathrm{b}}$ \\
\hline & \multirow[t]{3}{*}{ Epiloci259 } & 11 & $8 / 14$ & $0.35 \pm 0.17^{b}$ \\
\hline & & 00 & $2 / 14$ & $0.40 \pm 0.15^{\mathrm{ab}}$ \\
\hline & & 10 & $3 / 14$ & $0.06 \pm 0.02^{\mathrm{a}}$ \\
\hline & \multirow[t]{2}{*}{ Epiloci362 } & 11 & $9 / 14$ & $0.18 \pm 0.12^{\mathrm{b}}$ \\
\hline & & 10 & $3 / 14$ & $0.53 \pm 0.04^{\mathrm{a}}$ \\
\hline
\end{tabular}

Different letters indicate significant differences at the level of 0.05

The four types of MSAP bands 11 represents non-methylation, 10 represents hemimethylation, 01 represents inner methylation of double-stranded DNA (full methylation), and 00 represents full methylation
41.25 to $36.57 \%$ ) and increased in the susceptible group (from an average of 40.24 to $46.50 \%$ ) under HT stress, while no significant difference was detected in the moderate group (from an average of 41.69 to $42.44 \%$ ). Our results are consistent with a previous report showing that drought tends to cause a decrease in DNA methylation in tolerant genotypes and an increase in DNA methylation in sensitive genotypes (Abid et al. 2017). The present results suggest that changes in DNA methylation may be one of the important molecular mechanisms under HT stress.

Moreover, significant alterations in DNA methylation patterns were also detected after HT treatment. A significantly higher proportion of hypomethylation $(27.31 \%)$ was observed in the tolerant group than in the hypermethylation group $(20.20 \%)$. In contrast, the proportion of hypermethylation in the susceptible group (29.91\%) was significantly higher than that in the demethylation group (22.86\%). However, no significant difference was observed in this study between hypomethylation and hypermethylation levels in the moderate group. Similar results were also reported in rice (Xia et al. 2017), wheat (Kaur et al. 2018), and rapeseed (Gao et al. 2014) under osmotic, drought, and HT stresses, respectively. These authors reported that hypomethylation was more abundant in tolerant genotypes, whereas hypermethylation was more abundant in sensitive genotypes.

\section{Tolerant-Associated Epiloci Generated from Numerous Genotypes with Different Tolerances Have a High Probability to be Associated with High Temperature Tolerance}

Previous studies have reported that environmental stresses can cause great variations in DNA methylation between two genotypes of contrasting tolerances (Gao et al. 2014; Wang et al. 2016; Xia et al. 2017). However, it is difficult to determine whether these differences in DNA methylation between two genotypes are associated with their contrasting tolerances or merely with a different genetic background (Garg et al. 2015; Wang et al. 2016). In this study, the average similarity of the DNA methylation patterns between the two genotypes was $37.72 \%$. Theoretically, we could generate 275 DMEs between two rice genotypes. However, only 19 epiloci were identified as TAEs, accounting for $6.91 \%$ (19/275). In contrast, among the 14 rice genotypes, 44 DMEs were identified, and 19 of them were detected as TAEs, accounting for $43.18 \%$. Similarly, a high proportion of TAEs was also detected in 64 rice genotypes under osmotic stress (35.7\%) (Xia et al. 2017), suggesting that the DMEs generated from numerous genotypes would have a high probability of being associated with HT tolerance.

Among the 19 TAEs, 12 TAEs and 6 non-TAEs were cloned and sequenced and annotated into 18 genes 
Fig. 4 The relative expression of 12 TAE genes (a) and 6 nonTAE genes (b) (Color figure online)

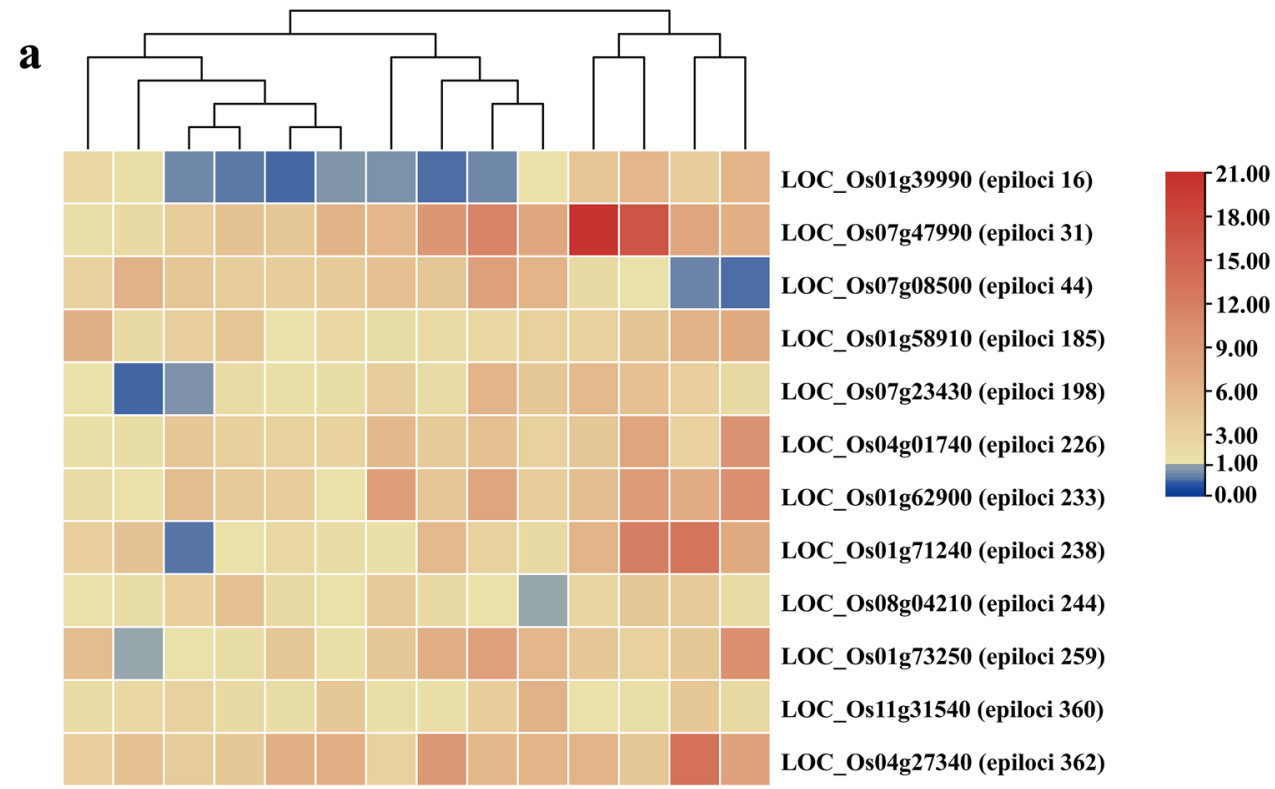

$\begin{array}{llllllllllllll}\text { S3 } & \text { S1 } & \text { S2 } & \text { M5 } & \text { S4 } & \text { M6 } & \text { M4 } & \text { M1 } & \text { M2 } & \text { M3 } & \text { T1 } & \text { T2 } & \text { T3 } & \text { T4 }\end{array}$

b

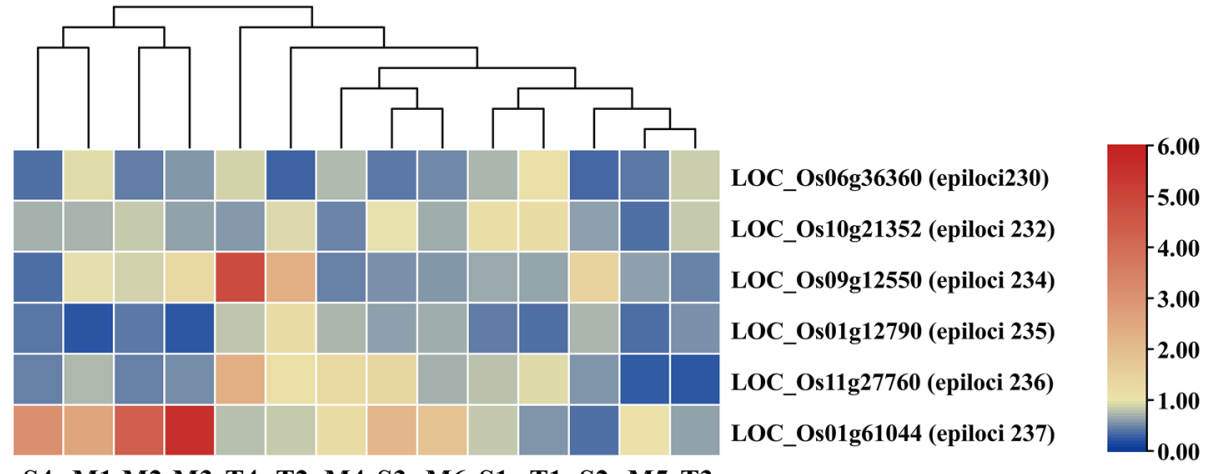

(Table S4). The GO annotation analysis indicated that these genes were involved in several biological processes (Table S4). LOC_Os04g01740 (epiloci 31) encodes a putative heat shock protein that has been reported to be associated with responses against HT stress in rice (Moon et al. 2014). LOC_Os04g27340 encodes a putative terpene synthase that plays an important role in producing terpene volatiles in response to abiotic stresses (Lee et al. 2015). qRT-PCR analysis showed that most of the 12 TAE genes were mainly upregulated in the 14 rice genotypes after HT treatment (Fig. 4a). Moreover, the 14 rice genotypes were clearly clustered into three groups according to the gene expression levels, which is similar to the HT tolerance classification. However, the 6 selected non-TAE genes were mainly downregulated or expressed at low levels after HT treatment, and the 14 rice accessions with the same HT tolerance were not clustered together (Fig. 4b). These results suggested that these non-TAE genes are not associated with HT tolerance. In short, these results may suggest that TAE genes may contribute to improving HT tolerance in rice, although this requires further evidence.

\section{Significance of Epigenetic Markers of DNA Methylation in the Breeding of Rice HT Tolerance}

HT is one of most serious environmental factors that limits crop growth and yield and can cause irreversible and undesirable changes that affect crop yield and quality, especially at the reproductive stage (Fahad et al. 2019; Fahad et al. 2021; Liu et al. 2020a; Xu et al. 2020; Kan and Lin 2021; Yan et al. 2021). High temperature could decrease rice yield by $40 \%$ by the end of the twenty-first century (Fahad et al. 2018). Therefore, conducting research on rice HT stress and cultivating high-temperature-resistant varieties is of great significance to increase rice yield and ensure global food security (Fahad et al. 2017; Fahad et al. 2020; Atif et al. 2021). To date, a number of genes (such as SLG1 and OsNTL3) or QTLs (such as qHTT8 and qHTB1-1) associated with HT tolerance have been identified to improve rice 
Fig. 5 Proposed model of DNA methylation involved in the response to HT stress in the different HT-tolerant rice genotypes. The red and green colors indicate a high and low level of DNA methylation patterns, respectively (Color figure online)

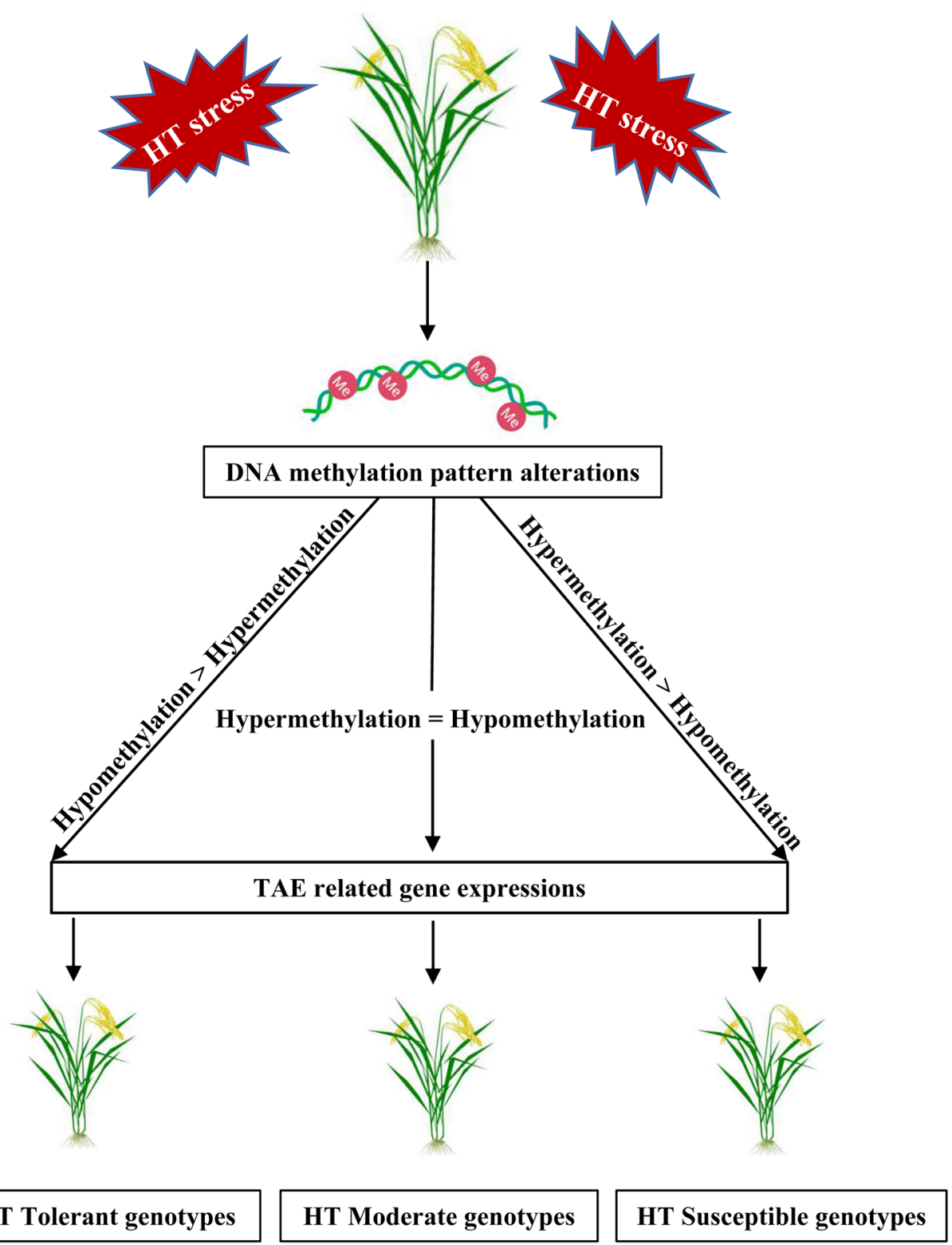

HT tolerance (Cao et al. 2020; Chen et al. 2020b; Liu et al. 2020b; Xu et al. 2020). However, HT tolerance is a complex trait that is regulated by multiple factors.

The loss of DNA methylation in a long interspersed nuclear element retrotransposon KARMA can reduce oil yield in oil palm (Ong-Abdullah et al. 2015), and the epigenetic diversity increases the productivity and stability of plant populations (Latzel et al. 2013). In this study, 19 TAEs with a significant impact on HTSI were identified, which could be used as good epigenetic markers for rice HT tolerance breeding. Epigenetic mechanisms play important roles in the process of plants adapting to various stresses (Alakärppä et al. 2018). Comparative analyses of histone modifications between salt-tolerant and salt-sensitive rice genotypes showed that significant differences occurred in genomic variations across $\mathrm{H} 3 \mathrm{~K} 4 \mathrm{me} 3$ and $\mathrm{H} 3 \mathrm{~K} 27 \mathrm{me} 3$, which were linked to the differential expression of the salt-responsive gene OsBZ8 (Paul et al. 2017). Demethylation in the promoter region of $H v A A C T l$ increased the expression level of $H v A A C T 1$ and improved resistance to aluminum stress in barley (Kashino-Fujii et al. 2018). All these results suggest that epigenetics should not be ignored in plant resistance breeding in addition to resistance genes. 


\section{Conclusions}

In this study, we found that HT-induced DNA methylation changes were associated with HT tolerance in rice at the anthesis stage. More DNA hypomethylation events occurred in the HT-tolerant group, while more hypermethylation occurred in the HT-susceptible group (Fig. 5). The HTmoderate group had similar proportions of hypomethylation and hypermethylation (Fig. 5). A brief model was proposed to summarize the DNA methylation responses in rice spikelets at the anthesis stage under HT condition (Fig. 5). Furthermore, a total of 19 TAEs were identified, and 12 of them were cloned and sequenced. qRT-PCR analysis indicated that the 12 TAE genes were mainly upregulated under HT stress and were highly associated with HT tolerance. These TAEs could be used as good epigenetic markers in HT tolerance breeding. Overall, this study may provide a basis for further studies into the role of epigenetic regulation in improving plant tolerance to environmental stress.

Supplementary Information The online version contains supplementary material available at https://doi.org/10.1007/s00344-022-10586-5.

Acknowledgements This work supported by Hubei Outstanding Youth Fund (2021CFA064), Hubei Key Research and Development Program (2021BBA225), Major R\&D Project of Hubei Agricultural Science and Technology Innovation Center (No.2020-620-000-002-01), Open Research Fund of State key laboratory of hybrid rice (KF201910), Open Research Fund of Hubei Engineering Research Center for Protection and Utilization of Special Biological Resources in the Hanjiang River Basin (202008), and Open Research Fund of Engineering Research Center of Ecology and Agriculture Use of Wetland (KFT202007).

Author Contributions $\mathrm{YX}$ and $\mathrm{CJ}$ conceived and designed the research; BL, HC, FY, BA, and RW carried out the experiments. BL, CZ, and RW analyzed the data; BL, KL, and YX wrote the manuscript. YX, BL, $\mathrm{CJ}$, and $\mathrm{CZ}$ revised the manuscript.

\section{Declarations}

Conflict of interest All authors declare that they have no conflict of interest.

Open Access This article is licensed under a Creative Commons Attribution 4.0 International License, which permits use, sharing, adaptation, distribution and reproduction in any medium or format, as long as you give appropriate credit to the original author(s) and the source, provide a link to the Creative Commons licence, and indicate if changes were made. The images or other third party material in this article are included in the article's Creative Commons licence, unless indicated otherwise in a credit line to the material. If material is not included in the article's Creative Commons licence and your intended use is not permitted by statutory regulation or exceeds the permitted use, you will need to obtain permission directly from the copyright holder. To view a copy of this licence, visit http://creativecommons.org/licenses/by/4.0/.

\section{References}

Abid G, Mingeot D, Muhovski Y, Mergeai G, Aouida M, Abdelkarim S, Aroua I, El Ayed M, M'hamdi M, Sassi K, Jebara M (2017) Analysis of DNA methylation patterns associated with drought stress response in faba bean (Vicia faba L.) using methylationsensitive amplification polymorphism (MSAP). Environ Exp Bot 142:34-44. https://doi.org/10.1016/j.envexpbot.2017.08.004

Alakärppä E, Salo HM, Valledor L, Cañal MJ, Häggman H, Vuosku J (2018) Natural variation of DNA methylation and gene expression may determine local adaptations of Scots pine populations. J Exp Bot 69(21):5293-5305. https://doi.org/10.1093/jxb/ery292

Alonso-Blanco C, Andrade J, Becker C, Bemm F, Bergelson J, Borgwardt K, Chae E, Dezwaan T, Wei D, Ecker J (2016) Epigenomic diversity in a global collection of Arabidopsis thaliana accessions. Cell 166(2):492-505. https://doi.org/10.1016/j.cell.2016.06.044

Atif B, Hesham A, Fahad S (2021) Biochar coupling with phosphorus fertilization modifies antioxidant activity, osmolyte accumulation and reactive oxygen species synthesis in the leaves and xylem sap of rice cultivars under high-temperature stress. Physiol Mol Biol Plants 27(9):2083-2100. https://doi.org/10.1007/ s12298-021-01062-7

Cao ZB, Li Y, Tang HW, Zeng BH, Tang XY, Long QZ, Wu XF, Cai YH, Yuan LF, Wan JL (2020) Fine mapping of the qHTB1-1 QTL, which confers heat tolerance at the booting stage, using an Oryza rufipogon Griff. introgression line. Theor Appl Genet 133(4):1161-1175. https://doi.org/10.1007/s00122-020-03539-7

Chang-Fung-Martel J, Harrison MT, Rawnsley R, Smith AP, Meinke $\mathrm{H}$ (2017) The impact of extreme climatic events on pasture-based dairy systems: a review. Crop Pasture Sci 68(12):1158-1169. https://doi.org/10.1071/CP16394

Chen C, Chen H, Zhang Y, Thomas HR, Frank MH, He YH, Xia R (2020a) TBtools: an integrative toolkit developed for interactive analyses of big biological data. Mol Plant 13(8):1194-1202. https://doi.org/10.1016/j.molp.2020.06.009

Chen L, Wang Q, Tang MY, Zhang XL, Pan YH, Yang XH, Gao GP, Lv RH, Tao W, Jiang LG, Liang TF (2020) QTL mapping and identification of candidate genes for heat tolerance at the flowering stage in rice. Front Genet 11:621871. https://doi.org/10.3389/ fgene.2020.621871

Duan H, Li JY, Zhu YQ, Jia WJ, Wang HH, Jiang LN, Zhou YQ (2020) Responsive changes of DNA methylation in wheat (Triticum aestivum) under water deficit. Sci Rep 10(1):1-8. https://doi.org/10. 1038/s41598-020-64660-7

Fahad S, Bajwa AA, Nazir U, Anjum SA, Farooq A, Zohaib A, Sadia S, Nasim W, Adkins S, Saud S, Ihsan MZ, Alharby H, Wu C, Wang DP, Huang JL (2017) Crop production under drought and heat stress: plant responses and management options. Front Plant Sci 8:1147. https://doi.org/10.3389/fpls.2017.01147

Fahad S, Adnan M, Hassan S, Saud S, Hussain S, Wu C, Wang DP, Hakeem KR, Alharby HF, Turan V, Khan MA, Huang JL (2019) Rice responses and tolerance to high temperature. In: Hasanuzzaman M, Fujita M, Nahar K, Biswas JK (eds) Advances in rice research for abiotic stress tolerance. Woodhead Publ Ltd, Cambridge, pp 201-224

Fahad S, Sonmez O, Saud S, Wang DP, Wu C, Adnan M, Turan V (eds) (2021) Climate change and plants: biodiversity, growth and interactions, first edition, footprints of climate variability on plant diversity. CRC Press, Boca Raton

Fahad S, Hussain S, Saud S, Hassan S, Ihsan Z, Shah AN, Wu C, Yousaf M, Nasim W, Alharby H, Alghabari F, Huang JL (2016) Exogenously applied plant growth regulators enhance the morphophysiological growth and yield of rice under high temperature. Front Plant Sci 7:1250. https://doi.org/10.3389/fpls.2016.01250 
Fahad S, Ihsan MZ, Khaliq A, Daur I, Saud S, Alzamanan S, Nasim W, Abdullah M, Khan IA, Wu C, Wang DP, Huang JL (2018) Consequences of high temperature under changing climate optima for rice pollen characteristics-concepts and perspectives. Arch Agron Soil Sci 64(11):1473-1488. https://doi.org/10.1080/03650340. 2018.1443213

Fahad S, Hasanuzzaman M, Alam M, Ullah H, Saeed M, Ali Khan I, Adnan M (eds) (2020) Environment climate plant and vegetation growth. Springer Nature, Switzerland AG. https://doi.org/10.1007/ 978-3-030-49732-3

Gao GZ, Li J, Li H, Li F, Xu K, Yan GX, Chen BY, Qiao JW, Wu XM (2014) Comparison of the heat stress induced variations in DNA methylation between heat-tolerant and heat-sensitive rapeseed seedlings. Breed Sci 64(2):125-133. https://doi.org/10.1270/ jsbbs.64.125

Garg R, Narayana Chevala V, Shankar R, Jain M (2015) Divergent DNA methylation patterns associated with gene expression in rice cultivars with contrasting drought and salinity stress response. Sci Rep 5(1):1-16. https://doi.org/10.1038/srep14922

Harrison MT, Cullen BR, Armstrong D (2017) Management options for dairy farms under climate change: effects of intensification, adaptation and simplification on pastures, milk production and profitability. Agric Syst 155:19-32. https://doi.org/10.1016/j.agsy.2017.04.003

Kan Y, Lin H-X (2021) Molecular regulation and genetic control of rice thermal response. Crop J 9(3):497-505. https://doi.org/10.1016/j. cj.2021.02.008

Kashino-Fujii M, Yokosho K, Yamaji N, Yamane M, Saisho D, Sato K, Ma JF (2018) Retrotransposon insertion and DNA methylation regulate aluminum tolerance in European barley accessions. Plant Physiol 178(2):716-727. https://doi.org/10.1104/pp.18.00651

Kaur A, Grewal A, Sharma P (2018) Comparative analysis of DNA methylation changes in two contrasting wheat genotypes under water deficit. Biol Plant 62(3):471-478. https://doi.org/10.1007/ s10535-018-0786-3

Lamelas L, Valledor L, Escandón M, Pinto G, Cañal MJ, Meijón M (2020) Integrative analysis of the nuclear proteome in Pinus radiata reveals thermopriming coupled to epigenetic regulation. J Exp Bot 71(6):2040-2057. https://doi.org/10.1093/jxb/erz524

Latzel V, Allan E, Silveira AB, Colot V, Fischer M, Bossdorf O (2013) Epigenetic diversity increases the productivity and stability of plant populations. Nat Commun 4(1):1-7. https://doi.org/10.1038/ncomm s3875

Lee GW, Lee S, Chung MS, Jeong YS, Chung BY (2015) Rice terpene synthase 20 (OsTPS20) plays an important role in producing terpene volatiles in response to abiotic stresses. Protoplasma 252(4):9971007. https://doi.org/10.1007/s00709-014-0735-8

Li B, Gong Q, Hua W, Chen GH, Zhang WY, Xu YH, Li CD (2020) Genetic and epigenetic variations in barley (Hordeum vulgare L.) using SSR and MSAP approaches. Genet Resour Crop Evol 68(2):729-739. https://doi.org/10.1007/s10722-020-01019-x

Liu GF, Xia YD, Liu TK, Dai SJ, Hou XL (2018) The DNA methylome and association of differentially methylated regions with differential gene expression during heat stress in Brassica rapa. Int J Mol Sci 19(5):1414. https://doi.org/10.3390/ijms19051414

Liu K, Deng J, Lu J, Wang XY, Lu BL, Tian XH, Zhang YB (2019) High nitrogen levels alleviate yield loss of super hybrid rice caused by high temperatures during the flowering stage. Front Plant Sci 10:357-364. https://doi.org/10.3389/fpls.2019.00357

Liu G, Zha ZP, Cai HY, Qin DD, Jia HT, Liu CY, Qiu DF, Zhang ZJ, Wan ZH, Yang YY, Wan BL, You AQ, Jiao CH (2020) Dynamic transcriptome analysis of anther response to heat stress during anthesis in thermotolerant rice (Oryza sativa L.). Int J Mol Sci. https://doi. org/10.3390/ijms21031155

Liu XH, Lyu YS, Yang WP, Yang ZT, Lu SJ, Liu JX (2020) A membrane-associated NAC transcription factor OSNTL3 is involved in thermotolerance in rice. Plant Biotechnol J 18(5):1317-1329. https:// doi.org/10.1111/pbi.13297

Moon JC, Ham DJ, Hwang SG, Park YC, Lee C, Jang CS (2014) Molecular characterization of a heat inducible rice gene, OsHSP1, and implications for rice thermotolerance. Genes Genom 36(2):151-161. https://doi.org/10.1007/s13258-013-0152-y

Mu QL, Zhang WY, Zhang YB, Yan HL, Liu K, Matsui T, Tian XH, Yang PF (2017) iTRAQ-based quantitative proteomics analysis on rice anther responding to high temperature. Int J Mol Sci 18(9):1811. https://doi.org/10.3390/ijms18091811

Ong-Abdullah M, Ordway JM, Jiang N, Ooi SE, Kok SY, Sarpan N, Azimi N, Hashim AT, Ishak Z, Rosli SK, Malike FA, BakarNAA MM, Abdullah N, Yaakub Z, Amiruddin MD, Nookiah R, Singh R, Low ETL, Chan KL, Azizi N, Smith SW, Bacher B, Budiman MA, Brunt AV, Wischmeyer C, Beil M, Hogan M, Lakey N, Lim CC, Arulandoo X, Wong CK, Choo CN, Wong WC, Kwan YY, Alwee SS, Sambanthamurthi R, Martienssen RA (2015) Loss of Karma transposon methylation underlies the mantled somaclonal variant of oil palm. Nature 525(7570):533-537. https://doi.org/10. 1038/nature15365

Pan R, Xu YH, Xu L, Zhou MX, Jiang W, Wang Q, Zhang WY (2020) Methylation changes in response to hypoxic stress in wheat regulated by methyltransferases. Russ J Plant Physiol 67(2):323-333. https:// doi.org/10.1134/s1021443720020120

Paul A, Dasgupta P, Roy D, Chaudhuri S (2017) Comparative analysis of histone modifications and DNA methylation at $O s B Z 8$ locus under salinity stress in IR64 and Nonabokra rice varieties. Plant Mol Biol 95(1):63-88. https://doi.org/10.1007/s11103-017-0636-2

Peakall R, Smouse PE (2006) GENALEX 6: genetic analysis in excel. Population genetic software for teaching and research. Mol Ecol Notes 6(1):88-295. https://doi.org/10.1111/j.1471-8286.2005. 01155.X

Qian YX, Hu WJ, Liao JY, Zhang J, Ren QY (2019) The dynamics of DNA methylation in the maize (Zea mays L.) inbred line B73 response to heat stress at the seedling stage. Biochem Biophys Res Commun 512(4):742-749. https://doi.org/10.1016/j.bbrc.2019.03. 150

Wang WS, Huang F, Qin Q, Zhao XQ, Li ZK, Fu BY (2015) Comparative analysis of DNA methylation changes in two rice genotypes under salt stress and subsequent recovery. Biochem Biophys Res Commun 465(4):790-796. https://doi.org/10.1016/j.bbrc.2015.08.089

Wang WS, Qin Q, Sun F, Wang YX, Xu DD, Li ZK, Fu BY (2016) Genome-wide differences in dna methylation changes in two contrasting rice genotypes in response to drought conditions. Front Plant Sci 7:1675. https://doi.org/10.3389/fpls.2016.01675

Wu C, Cui KH, Tang S, Li GH, Wang SH, Fahad S, Nie LX, Huang JL, Peng SB, Ding YF (2020) Intensified pollination and fertilization ameliorate heat injury in rice (Oryza sativa L.) during the flowering stage. Field Crop Res 252:107795. https://doi.org/10.1016/j.fcr. 2020.107795

Xia H, Huang WX, Xiong J, Yan SG, Tao T, Li JJ, Wu JH, Luo LJ (2017) Differentially methylated epiloci generated from numerous genotypes of contrasting tolerances are associated with osmotic-tolerance in rice seedlings. Front Plant Sci 8:11. https://doi.org/10.3389/fpls. 2017.00011

Xu YF, Zhang L, Ou SJ, Wang RC, Wang YM, Chu CC, Yao SG (2020) Natural variations of $S L G 1$ confer high-temperature tolerance in indica rice. Nat Commun 11(1):1-13. https://doi.org/10.1038/ s41467-020-19320-9

Yan HL, Zhang BL, Zhang YB, Chen XL, Xiong H, Matsui T, Tian XH (2017) High temperature induced glume closure resulted in lower fertility in hybrid rice seed production. Front Plant Sci 7:1960. https://doi.org/10.3389/fpls.2016.01960

Yan H, Harrison MT, Liu K, Wang B, Feng P, Fahad S, Meinke H, Yang R, Liu DL, Archontoulis S, Huber I, Tian XH, Man JG, Zhang YB, Zhou MX (2021) Crop traits enabling yield gains 
under more frequent extreme climatic events. Sci Total Environ 808(2022):152170. https://doi.org/10.1016/j.scitotenv.2021.152170

Zhang HM, Lang ZB, Zhu JK (2018) Dynamics and function of DNA methylation in plants. Nat Rev Mol Cell Biol 19(8):489-506. https:// doi.org/10.1038/s41580-018-0016-Z

Zhao JG, Lu ZG, Wang L, Jin B (2020) Plant responses to heat stress: physiology, transcription, noncoding RNAs, and epigenetics. Int J Mol Sci 22(1):117. https://doi.org/10.3390/ijms22010117
Publisher's Note Springer Nature remains neutral with regard to jurisdictional claims in published maps and institutional affiliations. 